\title{
Assessing grazing impacts by remote sensing in hyper-arid environments
}

\author{
DAVID SALTZ, HEIKE SCHMIDT, MARY ROWEN, ARNON KARNIELI, DAVID WARD, AND IRIS SCHMIDT
}

Authors are senior lecturer at Mitrani Center for Desert Ecology, Blaustein Institute for Desert Research, Ben Gurion University of the Negev, Sede Boqer Campus 84990, Israel; Ph.D. candidate at Remote Sensing unit, Blaustein Institute for Desert Research, Ben Gurion University of the Negev, Sede Boqer Campus; AAAS Science and Diplomacy Fellow, Washington DC; Researcher at the Remote Sensing unit, Blaustein Institute for Desert Research; senior lecturer at Mitrani Center for Desert Ecology and head of Ramon Science Center, Blaustein Institute for Desert Research; and field technician at the Ramon Science Center. Third author was formerly a Post-Doctoral fellow at the Ramon Science Center.

\section{Abstract}

Assessing vegetation status via remote sensing techniques using various vegetation indices has been successfully applied to semi-arid and arid environments. We tested the feasibility of applying such techniques for assessing grazing impact in hyper-arid environments with a high variance in soil type over space. An anticlinal erosional cirque called Makhtesh Ramon in the Negev desert, Israel, was selected for the study. The cirque is typified by low rainfall $(40-90 \mathrm{~mm}$ per year), a variety of soil substrates and is subject to grazing by a herd of Asiatic wild asses (Equus hemionus) reintroduced into the cirque between 1984 and 1987. As a control, we used an ungrazed dry riverbed south of the cirque that runs parallel to the riverbed draining the cirque. We used 5 common vegetation indices derived from Landsat 5 satellite Thematic Mapper (TM). Four images were used, representing dry and wet seasons in above- and below-average rainfall years (1995 and 1987, respectively). To test whether we can detect changes in plant community structure via satellite data we correlated vegetation indices from the TM to ground measurements made along the altitudinal gradient of the cirque. To test whether differences in plant cover could be detected, we correlated the vegetation indices with ground measurements of cover in and out of the cirque (grazed and ungrazed areas). Although ground measurements showed that community structure changed following grazing with altitudinal gradient and ground cover was $30 \%$ lower inside the cirque than outside the cirque, none of the 5 vegetation indices correlated with the ground measurements. Transformed Soil Adjusted Vegetation Index (TSAVI) and Normalized Difference Vegetation Index (NDVI) produced the best results. We hypothesize that the low vegetation cover that typifies hyper-arid environments increases the noise to signal ratio. Thus, a $30 \%$ decline in vegetation cover in this case is only an absolute decline of $4 \%$ from 15.8 to $11.2 \%$. Because TM is sensitive to absolute cover rather than the relative dif-

This study was funded by the International Arid Lands Consortium, The Fund for Threatened Wildlife of the Frankfurt Zoological Society, the Israel Nature Reserves Authority, and the Israel Ministry of Science. This is publication No. 279 of Mitrani Department of Desert Ecology and publication No. 75 of the Ramon Science Center.

Manuscript accepted 6 Dec. 1998. ferences, it is difficult to demonstrate differences among TM images. Using ANOVA to test the effect of season and grazing status on TSAVI and NDVI, we found a significant interaction between season and grazing status in 1995 with indices declining more from wet to dry season inside the cirque than outside the cirque. No such pattern was found in 1987. These data suggest that satellite imagery may detect changes in plant cover over time but can not serve as a direct index of plant cover in hyper-arid conditions.

Key Words: Asiatic wild ass, reintroduction, satellite, vegetation cover

\section{Resumen}

Se estimó el estado de la vegetación via técnicas de teledetección usando varios índices de vegetación que han sido satisfactoriamente aplicados a semi-áridos y áridos ambientes. Se ensayó la factibilidad de aplicar estas técnicas para estimar el impacto de la herbivoría en ambientes hiper-áridos con gran varianza del tipo de suelo en el terreno. El "Makhtesh Ramon", un anticlinal erosional círculo en el desierto del Negev, Israel, fue seleccionado para el estudio. El círculo es caracterizado por una baja precipitación (40-90 mm por año) y una variedad de sustratos edáficos, además es expuesto a forrajeo por un rebaño de asnos salvajes asiáticos (Equus hemionus) reintroducidos en el círculo entre 1984 y 1987. Como control, se uso un no forrajeado lecho seco de un rio al sur del círculo el cual corre paralelo a el lecho del rio drenando el círculo. Se usaron 5 índices de vegetación derivados del satélite Landsat 5 Thematic Mapper (TM). Cuatro imagenes fueron usadas, representando estaciones secas $y$ humedas en años con altos-y bajos- promedios de precipitación (1995 y 1987, respectivamente). Para probar si es posible detectar cambios en la estructura de la comunidad vegetal utilizando datos de satélite se corrrelacionaron los índices de vegetación del TM con mediciones de la vegetación hechas a lo largo de un gradiente altitudinal en el círculo. Para probar si las diferencias en covertura de la vegetación podrian ser detectadas, se correlacionaron los índices de vegetación con las medidas de covertura del suelo dentro y fuera del círculo (forrajeadas y no forrajeadas áreas). Aunque las mediciones 
de la vegetación muestran que la estructura de la comunidad cambia seguidamente del forrajeo cuando el gradiente altitudinal y la covertura del suelo fue $30 \%$ menor dentro del círculo que fuera del círculo, ninguna de los 5 índices de vegetación estan correlacionados con las medidas de la vegetación."Transformed Soil Adjusted Index" (TSAVI) y "Normalized Difference Vegetation Index" (NDVI) produjeron el mejor resultado. Nuestra hipótesis es que la baja covertura de la vegetación que tipifica los ambientes hyper-áridos incrementa la razón entre "el ruido y la señal". De este modo, un decrecimiento del $30 \%$ en la covertura de la vegetación en este caso es sólo un decrecimiento absoluto del $4 \%$ del 15.8 al $11.2 \%$. Debido a que el TM es sensitivo a la covertura absoluta antes que a las diferencias relativas, es dificil demostrar las diferencias entre imagenes del TM. Usando ANOVA para probar el efecto de las estaciones y el estado de forrajeo en TSAVI y NDVI, se encontró una interacción significante entre estaciones y estado de forrajeo en 1995 con los índices declinando más desde la estación humeda a la seca dentro del círculo que fuera del círculo. Este patrÛn no fue encontrado en 1987. Estos datos sugieren que las imagenes de satélite pueden detectar cambios sobre el tiempo pero no pueden servir como un directo índice de la covertura de la vegetación en condiciones hiper-áridas.

Remote sensing techniques have long been applied for the quantitative and qualitative evaluation of vegetation in semiarid ecosystems. Many studies have demonstrated their utility in assessing vegetation distribution (Colwell 1974, Justice et al. 1985, Sellers 1985, Tucker 1979) and their potential to overcome the manpower and fiscal restrictions that limit large-scale ecological surveys (Pickup et al. 1994). Visible and nearinfrared (NIR) multispectral images are the most useful data to examine vegetation patterns and corresponding ecological processes at regional and global scales. Vegetation indices (VI) (Elvidge and Chen 1995) derived from remotely sensed data have frequently been proposed as a method for predicting green biomass. In remote sensing applications VIs play a significant role for qualitatively and quantitatively evaluating vegetation cover by contrasting intense chlorophyll pigment absorption in the red against the high reflectivity of plant materials in the NIR (Tucker 1979). Specifically, indices of variables such as percent green cover, leaf area index (LAI) or absorbed photosynthetically active radiation (APAR) are sought (Anderson et al. 1993, Bannari et al. 1995, and Chilar et al. 1991).

More than any other regions, arid lands are susceptible to land degradation due to overgrazing and other human related activities. Because of the large-scale surveys required to assess such degradation, standard methodologies are often economically and logistically prohibitive, making remote sensing an attractive alternative (Pickup and Chewing 1994). However, vegetation sparseness in these regions means that soil is a dominant factor in remotely-sensed measurements, making measurement of plant cover complicated by the variability in the soil reflectance, as well as spectral interactions between the sparse plant canopies and the soil background.

Considerable effort in remote sensing has been focused on the optimization of soil-adjusted vegetation indices (Elvidge and Chen 1995, Huete 1986, 1988) and their successful application to semiarid regions (Foran 1987, Franklin 1991, Graetz et al. 1988, Pech et al. 1986, Williamson 1989). Studies on the use of remote sensing for assessing the impact of livestock grazing on vegetation cover and land degradation in arid and semiarid areas are numerous (Graetz and Gentle 1982, Bastin et al. 1993a, 1993b, Pickup et al. 1993, Pickup and Chewing 1994, Pickup 1995). However, no attempts have been made to use these techniques in hyper-arid environments. Hyper-arid environments are especialy problematic in this respect because of high spatial variance in soil types and high variance in vegetation cover over both space and time. In this study we apply and evaluate well-used VIs from satellite data for detecting grazing impacts in a hyper-arid environment, and compare it with ground measurements of vegetation.

\section{Methods}

\section{Study Area}

The study area was Makhtesh Ramon - an anticlinal $200 \mathrm{~km}^{2}$ erosional cirque in the southern boundary of the Negev highlands $\left(30^{\circ} 35^{\prime} \mathrm{N}, 34^{\circ} 45^{\prime} \mathrm{E}\right)$, Israel
(Fig. 1). The cique is elongated, running SW-NE with the floor tilted downwards towards the northeast. The Ramon dry riverbed, running NE down the center of the cirque exiting through a break in the southern rim, drains it. The north rim of the cirque consists of a sheer $200 \mathrm{~m}$ drop from the Negev highlands. Rim altitude ranges between 800 and $900 \mathrm{~m}$, while the cirque floor ranges from ca. $800 \mathrm{~m}$ at the SW edge to ca. $400 \mathrm{~m}$ in the NE basin. The southern rim is less steep, and is a ridge with a crest at about 510 m. A dry riverbed, Nahal Nekorot, runs parallel to the Ramon riverbed along the southern foothills of the southern rim. The altitudinal gradient from west to east along the Ramon and Nekorot riverbeds is correlated with rainfall, which ranges from about 95 $\mathrm{mm}$ in the southwest to about $40 \mathrm{~mm}$ in the northeast (Ward et al. 1993).

We selected Makhtesh Ramon for 3 reasons:

(1) A wide range of soil types and highly variable precipitation patterns typify the region. Exposed substrates include sandstone, gypsum, limestone, dolomite and various clays and several basalt hills (Danin 1983). The strong environmental changes (rainfall, and temperature) are reflected in the vegetation. The area is a transition from the steppe vegetation in the north to the true desert vegetation in the south (Ward and Olsvig-Whittaker 1993, Ward et al. 1993). The vegetation consists mostly of perennials. The cover and the diversity of the vegetation are higher in the wadis than on the rim and on the hills. For further details of the substrates and vegetation communities in Makhtesh Ramon, see Ward et al. (1993).

(2) Human pressure in Makhtesh Ramon and neighboring areas has increased considerably over the past decade, including tourism by off road vehicles and increased military activity that may induce land degradation and erosion.

(3) The successful reintroduction of an Asiatic wild ass (Equus hemionus) population into this region and its projected rapid growth rate may lead to eventual overgrazing. The reintroduction began in 1982 and included 4 releases totaling 28 animals (14 males and 14 females). The population has adapted well to the wild and grew rapidly. In 1996 the population was estimated at 100 animals and is expected to double by 2006 (Saltz and Rubenstein 1995). 


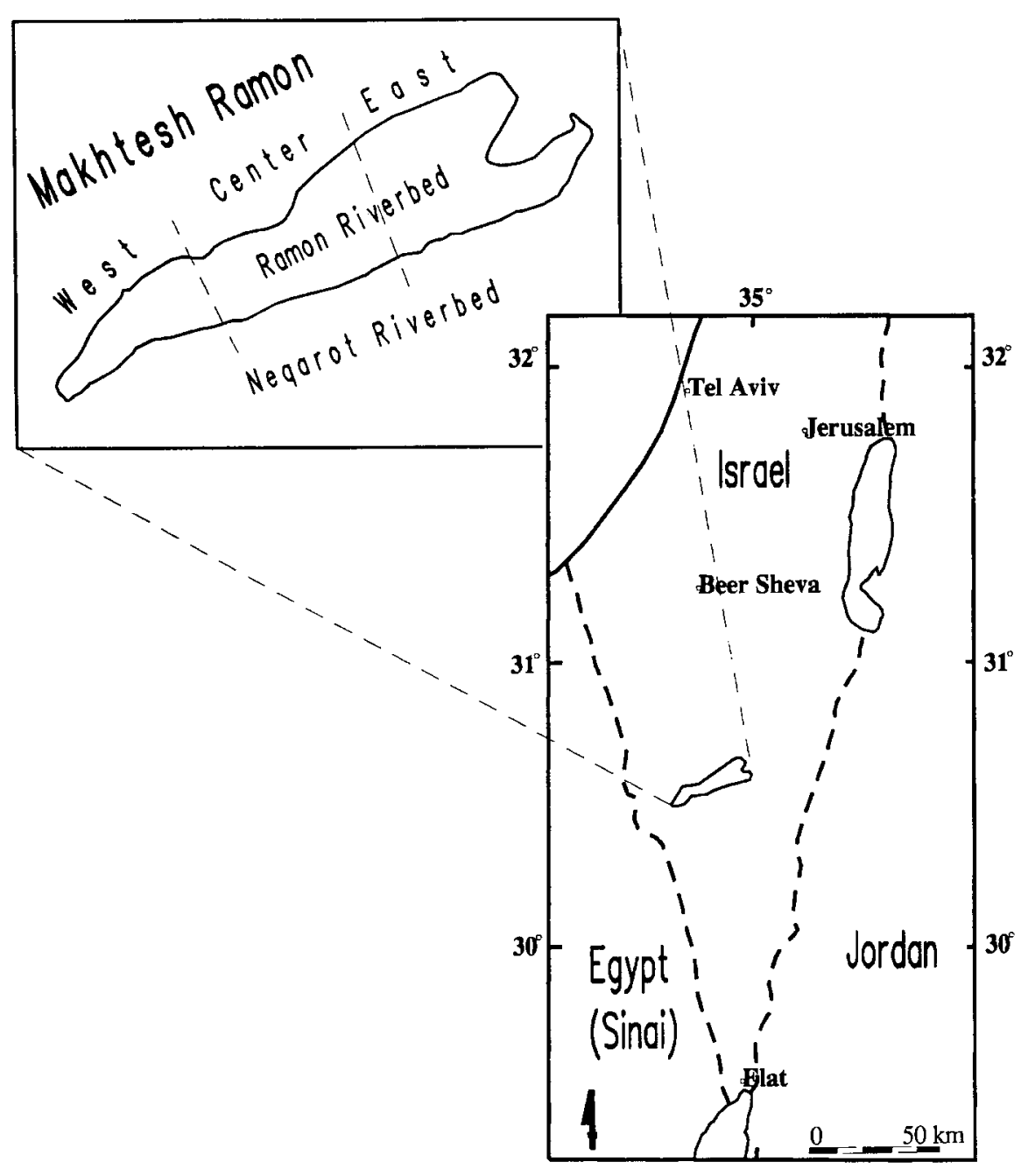

Fig. 1. The study areas in Israel.

\section{Satellite Data Processing}

We used 4 Landsat 5 Thematic Mapper (TM) images of the study region with a spatial resolution of $30 \mathrm{~m}$. The satellite images represent the end of rainy (March-April) and dry season (August-September) of the years 1987 and 1995 . Winter $1986 / 87$ was dry with less than average rainfall, while winter 1994/95 had an above average rainfall. Therefore, the Landsat TM images from 1987 and 1995 represent "wet" and "dry" years, respectively.

The pre-processing of the Landsat TM data in this study includes several correction algorithms carried out in several steps, including radiometric, atmospheric, and geometric corrections of the Landsat TM data (the thermal channel TM6 was not included in the processing):

(1) Radiometric correction-this is the conversion of the TM 8-bit digital numbers into physical quantities of radiance approach. This approach was applied for the 1987 images. Based on the dark surfaces in the Makhtesh Ramon (basalt hills), which are stable and not covered by vegetation. Spectral variability in all wavelengths between the images was checked. All images show a low variability. The differences between the atmospherically corrected and uncorrected vegetation indices for the basalt hills (where atmospheric impacts are expected to be the greatest) were minor $(<1 \%)$. We concluded that water vapor and aerosol content in the atmosphere during acquisition of the Landsat TM data 1987 were very small. Consequently, and after a visual interpretation of the 1987 images revealed they were very clear without any atmospheric "noises", we decided the 1987 images could be compared with the atmospheric corrected 1995 images. Measurements of aerosol and water vapour content were available for the 1995 images from a ground measurement station in Sede Boqer. Estimates of total precipitable water and aerosol properties of the atmosphere were obtained from an automatic sun tracking photometer at Sede Boqer. Atmospheric correction of the TOA reflectance was carried out using the $6 \mathrm{~S}$ algorithm (Vermote et al. 1996). In this study, we also used the $6 \mathrm{~S}$ code to calculate the TOA reflectance for the $1987 \mathrm{TM}$ images.

(3) Geometric corrections-were done so that the Landsat TM data had the same geometrical information as the ground observations (Jensen 1986). These errors were corrected using Ground Control Points (GCPs) on the surface of the earth where both image coordinates and map coordinates could be identified with acceptable accuracy. All 4 Landsat-TM images were rectified based on 23 well-distributed control points. We used a first order polynomial equation to convert the file coordinates to rectified map coordinates. The new rectified images were resampled with the nearest neighbor resampling method to a pixel size of $30 \mathrm{~m}$.

\section{Satellite Data Analysis}

Many different methods exist for reducing background influence on vegetation indices (VIs). We selected and compared 5 VIs from 2 groups that characterise the vegetation cover. The 
first group are VIs based on the Red/Near-infrared (R/NIR) slope. This group of VIs is used when there are strong influences of soil (background) brightness on vegetation indices, and special VIs must be applied in order to reduce the background noises (Huete 1986, Huete and Jackson 1987). From this group we selected 3:

(1) Normalized Difference Vegetation Index (NDVI - Rouse et al. 1974), where:

$$
N D V I=\frac{(N I R-R)}{(N I R+R)}
$$

(2) Soil Adjusted Vegetation Index (SAVI-Huete 1988) is defined by an additional soil adjustment factor $(L)$. In our case, we defined $L=1$, because of the sparse vegetation cover.

$$
S A V I=\left[\frac{(N I R-R)}{(N I R+R+L)}\right] * 2 .
$$

(3) Modified SAVI (MSAVI-Qi et al. 1994) is a modification of the SAVI, where the factor $L$ is not constant and varies inversely with the amount of vegetation present.

$M S A V I=\frac{\left.2 N I R+1-\sqrt{(2 N I R+1)^{2}-[8(N I R-R)}\right]}{2}$

The second group of VIs we used is based on the perpendicular distance in relation to the bare soil line. From this group we selected 2:

(1) Perpendicular Vegetation Index (PVI-Richardson and Wiegand 1977), where:

$$
\mathrm{PVI}=\frac{(N I R-a R-b)}{\sqrt[2]{a 2+1}}
$$

and $a$ and $b$ are the slope and intercept of the bare soil line.

(2) Transformed SAVI (TSAVI-Baret et al. 1989).

$$
\text { TSAVI }=\frac{[a(N I R-a R-b]}{(\mathrm{R}+\mathrm{aNIR}-\mathrm{ab})}
$$

where $a$ and $b$ are the slope and intercept of the bare soil line.

The bare soil line for the Makhtesh Ramon cirque was estimated by means of the reflectance values in the red band (TM3) regressed against the means in the near-infrared band (TM4) of selected bare surfaces inside the cirque.

\section{Ground Measurements and \\ Comparison to Satellite Data}

To test our ability to detect differences in vegetation cover and grazing impact through satellite imagery we compared our satellite data with ground measurements. We carried out 2 separate series of ground measurements to assess whether:

(1) we can detect changes in plant community structure through satellite data, and

(2) we can detect differences in vegetation cover (grazing pressure) through satellite data.

In the first series we sampled 8 circular plots with a $26 \mathrm{~m}$ diameter located along the long axis of the cirque, following the most significant environmental gradient, altitude (Ward et al. 1993). This is an effective means of sampling the maximum potential variation in plant-species composition in large areas and captures more information about vegetation attributes than randomly placed plots similar size (Gillison and Brewer 1985). In the second series we divided the cirque into 3 areas along the altitudinal gradient: western, central and eastern, and paired them with 3 parallel areas south of the cirque in the Nekorot riverbed. In each area we sampled 5 circular plots with a $26 \mathrm{~m}$ diameter. We sampled these areas twice, at the end of the rainy season (March 1995) and at the end of the dry season (September 1995). From personal observations of Asiatic wild ass behavior we knew that they spent far more time grazing/browsing in the 3 areas inside the cirque than in the 3 areas outside. Thus, our comparisons were made between plots with high and low herbivory, respectively.

We used the log-series survey sampling method to quantify plant density and cover of perennial vegetation. This method is appropriate for use in arid environments where perennial ramets are fairly distinct and separate (McAuliffe 1990, Ward et al. 1993). Numbers of individual ramets for each species within a plot are assessed. These numbers are used to assign species to logarithmic density classes equivalent to the logarithmic (base 2) values of actual abundances. The species is assigned to a $\log _{2}$ canopy class based on the median canopy diameter of the species in the plot. $\log _{2}$ total cover per plot is determined by adding logarithmic density and cover classes. Percent cover is derived by taking the antilog of the difference between $\log _{2}$ cover per species and $\log _{2}$ total plot area. We carried out 2 separate sets of measurements. In the first set we selected 8 plots along the altitudinal gradient within the Ramon cirque. In the second we carried out, within each of the 6 areas (3 inside and 3 outside the cirque) mentioned above, 5 McAuliffe plots that were placed within $30 \mathrm{~m}$ of one another on the same substrate.

Plant species richness was defined as the number of species per McAuliffe plot. We used Shannon-Wiener's index of species diversity from the plot data, following Magurran (1988). Ordinations of community structure was done by Detrended Correspondence Analysis (DECORANA). This is an improved eigenvector technique based on reciprocal averaging (also called correspondence analysis) but correcting its main faults (Hill and Gauch 1980). Reciprocal averaging (RA) can be viewed geometrically as the derivation of new axes which maximally account for the structure of points (=sample plots or species) in a multidimensional cloud of points, making possible the reduction of dimensionality. Algebraically, RA uses simple matrix algebra to obtain reciprocal weighted averages of sample and species scores by iteration. These weighted averages are used for ordinating samples and/or species. The 2 main faults of reciprocal averaging are:

(1) The undesirable 'arch' effect that occurs in second and higher order axes. This arch is undesirable because it causes a systematic relationship between the second and first axes.

(2) The compression of the first axis ends relative to the middle so that a given distance of separation in the ordination does not have a consistent meaning in terms of implied differences between samples or species (Gauch 1982). DECORANA is so-named because it detrends the undesirable arch effect that occurs in second and higher order axes in reciprocal averaging (Gauch 1982). DECORANA is an indirect ordination technique and, as such, ordinations of samples with particular environmental variables must be done after the ordination values have been obtained. In practice, this process involves regressing ordination scores on 1 or several axes with each environmental variable in turn. 
To validate our observations on Asiatic wild ass activity, we estimated the degree of herbivory and intensity of habitat. Degree of herbivory was estimated in the McAuliffe plots mentioned above by recording the degree of herbivory on 5 plants from each of the 5 most abundant plant species. We ranked each plant according to the degree of herbivory as $0=$ no herbivory; $1=<50 \%$ of external branches eaten, and $2=>50 \%$ external branches eaten. We indexed intensity of habitat use by faecal counts. Density of faecal piles was recorded on 5 parallel $250 \mathrm{~m}$-long transects walked along Asiatic wild ass routes of travel in each of the six areas. Perpendicular distance to each pile was recorded along the length of the transect. Density was calculated using distance sampling techniques (Buckland et al. 1993).

We compared satellite data to ground measurements by standard regression procedures. We did separate regression for each of the 5 vegetation indices (VIs). For the first series we selected 8 sub-sections of $3 \times 3$ pixels $(90 \times 90 \mathrm{~m})$, each sub-section covering one of the ground measurement plots. We ran regressions with VIs derived from dry season (September 1995) and wet season (March 1995) TMs. For the second series we selected randomly, from each of the 6 areas, 3 sections of $3 \times 3$ pixels from the same Thematic Mapper section TMs in the general areas of the 5 ground measurement circular plots. We regressed the mean VIs of the 3 sections in each area on the mean cover calculated from the 5 circular plots.

\section{Results}

\section{Satellite Data Processing}

The influence of the atmospheric correction on the reflectance values in Thematic Mapper ${ }^{\mathrm{TM}}$ channels 1-5 and 7 indicate that deviations vary with surface type (Table 1). In 5 of the 6 wavebands, corrected values deviated significantly from uncorrected values $(\mathrm{P}<0.05$, sign test). Changes in the reflectance value after the atmospheric correction were the greatest in the blue waveband (TM1) the near- and middle infrared bands (TM4-5, 7). This is mainly caused by molecular and aeroscattering in the blue band and water vapour absorption in the near- and middle infrared bands. In the blue waveband (TM1) the correc-

Table 1. Average Delta (atmospheric corrected and uncorrected reflectance values) for different surface types.

\begin{tabular}{lcrrrrr}
\hline \hline & TM1 & TM2 & TM3 & TM4 & TM5 & TM7 \\
\hline Spring image 1995 (03/95) & & & & & & 0.026 \\
Area with dense vegetation & -0.017 & 0.002 & 0.006 & 0.026 & 0.031 & 0.002 \\
Basalt (dark surface type) & -0.025 & -0.017 & 0.009 & 0.006 & 0.006 & 0.028 \\
Gypsum (bright surface type) & -0.013 & 0.010 & 0.015 & 0.028 & 0.035 & \\
Fall image 1995 (09/95) & & & & & & 0.039 \\
Area with dense vegetation & -0.007 & 0.009 & 0.012 & 0.025 & 0.035 & 0.012 \\
Basalt (dark surface type) & -0.011 & -0.003 & 0.002 & 0.009 & 0.012 & 0.037 \\
Gypsum (bright surface type) & -0.004 & 0.015 & 0.017 & 0.029 & 0.040 & \\
\hline
\end{tabular}

tion resulted in a decrease of the reflectance value, especially for areas with dense vegetation cover and dark surface colour. In the near-infrared waveband (TM4), water vapour absorption is responsible for the magnitude of the correction. The difference between TM3 and TM4 (red-near-infrared) increased after the atmospheric correction. The atmospheric effects are less important over bright surfaces with less vegetation cover. After rainfall, when all different vegetation components respond photosynthetically and the bright desert surface changes to a darker surface, the effects of atmospheric noises increased. Slope and intercept of the bare soil line were 1.305 and 0.0313 $\left(r^{2}=0.991\right)$, with basalt at the lower end and gypsum at the upper end.

\section{Ground Measurements and Vegetation Indices}

In the first series the Standard Deviation of the 9 pixels from the TM image in each subsection was very small. Therefore, the areas can be considered as very homogeneous and suitable for a comparison with the ground measurements. However, although coefficient of variation $(\mathrm{CV})$ for the cover estimation in the 8 plots using the ground measurements were high $(\mathrm{CV}=0.381$, range $=20.0-77.8 \%)$, none of the vegetation indices (VIs) used correlated well with ground measurements (Table 2). The Normalized Difference Vegetation Index (NDVI) and the Transformed Soil Adjusted Vegetation Index (TSAVI) had the highest correlation between percent vegetation cover and VI value, albeit non-significant $\left(\mathrm{R}^{2}=0.471, \mathrm{P}=0.060\right.$ and $\mathrm{R}^{2}=0.471$, $\mathrm{P}=0.059$, respectively).

In the second series, we found no relationship between ground measurements and the satellite data, with $\mathrm{R}^{2} \leq 0.1$ for all VIs. However, based on our ground measurements, percent vegetation cover was significantly higher in Nekorot dry riverbed outside the cirque than along the Ramon riverbed inside the cirque (15.8 \pm 1.5 vs. $11.2 \pm 0.9, \mathrm{P}<0.016)$. The results were consistent for each of the 3 areas $(10.4 \pm 1.7$ vs. $17.3,11.9 \pm 1.7$ vs. $15.3 \pm 2.4$, and 11.2 vs. 15.8 for the west center and east, respectively) with no significant difference in the ground measurements between the east center and west areas. Density of Asiatic wild ass dung piles was $74.4 \pm 19.8 /$ ha inside the cirque as compared with $15.0 \pm 9.5 /$ ha outside the cirque $(\mathrm{P}=0.022)$. The median index of herbivory was 1,2 and 1 for the east, center and west areas inside the cirque and was 0 for all areas outside the cirque. To make sure that differences in ground measurements were not due to differences in species composition, we calculated the Morisita-Horn index of plot similarity (Magurran 1988) for comparison made between plots inside to those outside the cirque and within plots inside and outside the cirque. Similarity between plots inside and outside the cirque was $1.18 \pm 0.42$, $1.46 \pm 0.25$, and $1.32 \pm 0.43$ for the west, center and eastern areas, respectively, and did not differ from the 'within' indices $(1.32 \pm 0.39,1.56 \pm 0.33$, and $1.38 \pm 0.47, \mathrm{P}=0.251,0.260$, and 0.681 , respectively).

Table 2. Correlation of vegetation indices with percent vegetation cover determined by ground measurements.

\begin{tabular}{lccc}
\hline \hline Index & $\begin{array}{c}\text { Dry } \\
\text { season }\end{array}$ & $\begin{array}{c}\text { Wet } \\
\text { season }\end{array}$ & $\begin{array}{c}\text { Seasonal } \\
\text { variation }\end{array}$ \\
\hline NDVI & $\mathrm{R}^{2}$ & $\mathrm{r}^{2}$ & $\mathrm{r}^{2}$ \\
SAVI & 0.227 & 0.471 & 0.048 \\
MSAVI & 0.005 & 0.003 & 0.033 \\
PVI & 0.109 & 0.003 & 0.004 \\
TSAVI & 0.212 & 0.473 & 0.019 \\
\hline
\end{tabular}


Table 3. Analysis of variance for the TSAVI vegetation index (after an arcsin transformation) comparing seasons (dry vs. wet), areas (west, center and east parts of the study area) and grazing status (grazed vs. ungrazed). 1987 and 1995 were analyzed separately.

\begin{tabular}{lllll}
\hline \hline 1987 & Source & DF & F value & P \\
\hline \multirow{2}{*}{1995} & Season & 1 & 50.4 & 0.0001 \\
& Area & 2 & 4.9 & 0.015 \\
& Grazing status & 1 & 5.2 & 0.030 \\
& Season * Grazing status & 1 & 4.41 & 0.045 \\
& Source & & & \\
& Season & DF & F value & P \\
Area & 1 & 79.8 & 0.0001 \\
& Grazing status & 2 & 7.7 & 0.002 \\
& Season * Grazing status & 1 & 8.3 & 0.008 \\
& Area * Grazing status & 1 & 7.0 & 0.014 \\
& & 2 & 8.6 & 0.001 \\
\hline
\end{tabular}

Analyses of variance for the best performing VIs (TSAVI and NDVI) were carried out separately for 1987 and 1995 using season, area (east, center or west) and grazing status (in and out of the cirque) as predictors. In 1987 only the effect of season and grazing status were significant with no significant interactions (Table 3). The mean VI value was $10 \%$ higher outside the cirque in both seasons. In 1995, grazing status and area were significant (Table 3), as well as the interaction between season and grazing status and area and grazing status. Mean VI during the wet season was $10 \%$ higher in the grazed area (inside the cirque) during the wet season, but declined in the dry season to the same level as the ungrazed area (Fig. 2).

\section{Discussion}

Our ground measurements showed that there was a $30 \%$ decline in vegetation cover from the grazed to the ungrazed area (from $15.8 \%$ to $11.2 \%$ ). However, we were unable to correlate vegetation indices (VIs) from satellite imagery to these values. An ANOVA on the VIs from the 1995 Thematic Mappers (TMs) produced a significant interaction between season and grazing status with cover declining more in the grazed area from the wet to the dry season. No such pattern was evident in the 1987 TM data. This may be indicative of increased grazing pressure in recent years inside the cirque. However, 1987 was a dry year and is, therefore, a weak control. Regretfully, there are no clear TM images from wet years at the early stage of the reintroduction (1987 and earlier).

Strong differences in VIs were found between seasons and years suggesting the low ground cover that typifies hyper-arid environments. In our case a decline of $30 \%$ in ground cover is associated with an absolute decline of only 15.6-11.2=4.6\%. Makhtesh Ramon cirque is characterised by a heterogeneous geology, which is covered by sparse vegetation (Ben-Dor et al. 1995, Kaufmann 1988, Ward et al. 1993). Therefore, the background colour and brightness has a much greater impact on the vegetation index than over a homogeneous surface. Thus, the 'noise' caused by the high variance in soil reflectance combined with highly variable rainfall patterns may overshadow any grazing effects that might exist. This result is consistent with the conclusion of Ezra et al. (1984) that satellite derived VIs may be less useful in arid than in mesic enviungrazed areas using VIs may be due to
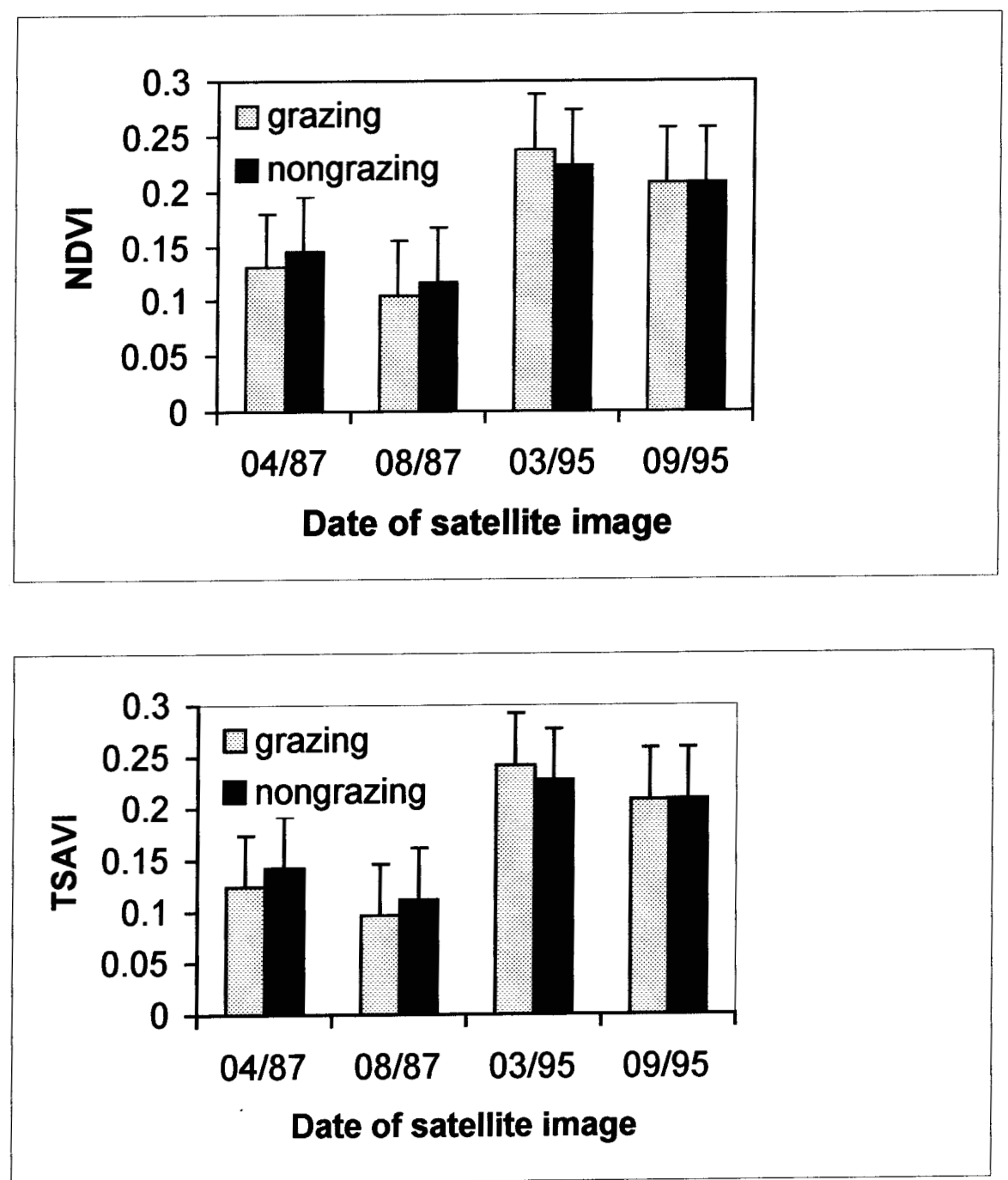

Fig. 2. Mean Vegetation Indices (VIs) for Normalized Difference Vegetation Index (NDVI) and Transformed Soil Adjusted Vegetation Index (TSAVI) for year, season and comparing grazed and ungrazed areas. 
ronments due to the influence of soil background on the radiometric signal.

We conclude that although grazing impacts may exist, at their current levels we are unable to detect them via satellite imagery. This is problematic because while an absolute decline in vegetation cover of $5 \%$ may be negligible in wetter areas with $50 \%$ cover, in areas with 10 $15 \%$ cover this constitutes a considerable reduction in carrying capacity. The significant interaction between grazing status and season in 1995 suggests that it may be possible to detect small changes in cover, but this level of change is not sufficient as a direct index of existing ground cover. However, to use changes in ground cover, a baseline pattern must be established (such as a TM from a wet year prior or shortly after the first reintroduction).

The difference between TM3 and TM4 ( $\Delta$ red-near-infrared) increased after the atmospheric correction. This change is important for the calculation of vegetation indices, which are based on the red and near-infrared part of the spectrum. The atmospheric effects are typically less important over bright surfaces with less vegetation cover. After rainfall, when all different vegetation components respond photosynthetically and the bright desert surface changes to a darker surface, the effects of atmospheric "noises" increased. These results emphasise the importance of the atmospheric effects (molecular and aerosol scattering, and water vapour absorption) in Landsat TM measurements of surface reflectance in a desert environment. The importance and accuracy required of atmospheric correction depends on the purpose for which the data are to be used. Studies based on satellite data for comparison of different areas or satellite data acquired at different times should consider, and correct for, the "noise" effect of the atmosphere.

\section{Literature Cited}

Anderson, G L., J. D. Hanson, and R.H. Haas. 1993. Evaluating Landsat TM derived vegetation indices for estimating above-ground biomass on semiarid rangelands. Remote Sens. Environ. 45, 165-175.

Bannari, A., D. Morin, F. Bonn, and A.R. Huete. 1995. A review of vegetation indices. Remote Sensing Rev. 13, 95-120.
Baret, F., G. Guyot, and D.J. Major. 1989. TSAVI: a vegetation index which minimizes soil brightness effects on LAI and APAR estimation. Proceedings of the 12th Canadian Symposium on Remote Sensing, IGARRS 90, Vancouver, Canada, 3, 1355-1358.

Bastin, G.N., A. D. Sparrow, and G. Pearce. 1993b. Grazing gradients in Central Australian rangelands: Ground verification of remote sensing-based approaches. Rangeland J. 15, 217-233.

Bastin, G.N., G. Pickup, V. H. Chewings, and G. Pearse. 1993a. Land degradation assessment in Central Australia using a grazing gradient method. Rangeland J. 15, 190-216.

Ben-Dor, E., and F.A. Kruse. 1995. Surface mineral mapping of Makhtesh Ramon Negev, Israel using GER 63 channel scanner data. Int. J. Remote Sens. 16, 3529-3553.

Buckland, S. T., D. R. Anderson, K. P. Burnham and J. L. Laake. 1993. Distance Sampling: Estimating abundance of biological populations. Chapman \& Hall, NY, 446pp.

Chilar, J., L. St-Laurent, and J. A. Dyer. 1991. Relationship between the normalized difference vegetation index and ecological variables. Remote Sens. Environ. 35, 279-298.

Colwell, J.E. 1974. Vegetation canopy reflectance. Remote Sens. Environ. 3, 175-183.

Danin, A. 1983. Desert vegetation of Israel and Sinai. Canaan Press, Jerusalem.

Elvidge, C. D. and Z. Chen. 1995. Comparison of broad-band and narrowband red and near-infrared vegetation indices. Remote Sens. Environ. 54, 38-48.

Ezra, E. G., L. R. Tinney, and R. D. Jackson. 1984. Effect of soil background on vegetation discrimination using Landsat data. Remote Sens. of Environ. 16:233-242.

Foran, B.D. 1987. Detection of yearly cover change with Landsat MSS on pastoral landscapes in Central Australia. Remote Sens. Environ. 23, 333-350.

Franklin, J. 1991. Land cover stratification using Landsat TM data in Sahelian and Sudanian woodland and wooded grassland. J.Arid Environ. 20, 141-163.

Fraser, R., and Y. Kaufmann. 1985. The relative importance of aerosol scattering and absorption in remote sensing. IEEE Trans. on Geoscience and Remote Sensing 23, 625-632.

Gauch, H.G. 1982. Multivariate analysis in community ecology. Cambridge Univ. Press, Cambridge.

Gillison, A.N. and K. R. W. Brewer. 1985. The use of gradient directed transects or gradsects in natural resource surveys. J. Environ. Manage. 20: 103-127.
Graetz, R.D. and M.R. Gentle. 1982. The relationship between reflectance in the Landsat wavebands and the composition of an Australian semi-arid shrub rangeland. Photogrammetric Engineering and Remote Sensing 48, 1721-1730.

Graetz, R.D., R. P. Pech, and A.W. Davis. 1988. The assessment and monitoring of sparsely vegetated rangelands using calibrated Landsat data. Int. J. Remote Sensing 9, 1201-1222.

Hill, M.O. and H. G. Gauch. 1980 . Detrended correspondence analysis, an improved ordination technique. Vegetatio 42: 47-58.

Huete, A. 1986. Separation of soil-plant spectral mixtures by factor analysis. Remote Sens. Environ. 19, 237-251.

Huete, A. 1988. A soil-adjusted vegetation index (SAVI). Remote Sens. Environ. 25, 295-309.

Huete, A. and R.D. Jackson. 1987. Suitability of spectral indices for evaluating vegetation characteristics on arid rangelands. Remote Sens. Environ. 23, 213-232.

Jensen, R. 1986. Introductory digital image processing. Prentice-Hall, Englewood Cliffs, New Jersey, 379 pp.

Justice, C.O., J. R. G. Townshend, B. N. Holben, and C.J. Tucker. 1985. Analysis of the phenology of global vegetation using meteorological satellite data. Int. J. Remote Sensing 6, 1271-1318.

Kaufmann, H. 1988. Decorrelation processing and evaluation of Landsat TM data as applied to Makhtesh Ramon. Israel J. of Earth Sciences, Vol. 37, 137-143.

Magurran, A. E. 1988. The measurement of species diversity. Chapman \& Hall, London.

Markham, B.L. and J.L. Barker. 1986. Landsat-MSS and TM post calibration dynamic ranges, atmospheric reflectance and at-satellite temperature. EOSAT Landsat Technical Notes 1, August 1986, Earth Observation Satellite Company, Lanham, Maryland, USA, 3-8 pp.

McAuliffe, J.R. 1990. A rapid survey method for the estimation of density and cover in desert plant communities. J. Veg. Sci. 1: 653-656.

Pech, R.P., A. W. Davis, R. R. Lamacraft, and R.D. Graetz. 1986. Calibration of Landsat data for sparsely vegetated semiarid rangelands. Int. J. Remote Sensing 7, 1729-1750.

Pickup, G. 1995. A simple model for predicting herbage production from rainfall in rangelands and its calibration using remotely-sensed data. J. Arid Environ. 30, 227-245.

Pickup, G. and V.H. Chewings. 1994. A grazing gradient approach to land degradation assessment in arid areas from remotely-sensed data. Int. J. Remote Sensing 15, 597-617. 
Pickup, G., G. N, Bastin, and V.H. Chewings. 1994. Remote-sensing-based condition assessment for nonequilibrium rangelands under large-scale commercial grazing. Ecol. Appl. 4, 497-517.

Pickup, G., V. H. Chewings, and D.J. Nelson. 1993. Estimating changes in vegetation cover over time in arid rangelands using Landsat MSS data. Remote Sens. Environ. 43, 243-263.

Qi, J., A. Chehbouni, A. Huete, Y. H. Kerr, and S. Sorooshian. 1994. A modified soil adjusted vegetation index. Remote Sens. Environ. 48, 119-126.

Richardson, A. J. and C.L. Wiegand 1977. Distinguishing vegetation from soi background information. Photogrammetric Eng. and Remote Sensing 43, 1541-1552.

Rouse, J.W., R. H. Haas, J. A. Schell, D. W. Deering, and J.C. Harlan. 1974. Monitoring the Vernal Advancements and Retrogradation (Greenwave Effect) of Nature Vegetation. NASA/GSFC Final Report, NASA, Greenbelt, MD, 371 pp.
Saltz, D. and D. I. Rubenstein 1995. Population dynamics of a reintroduced Asiatic wild-ass (Equus hemionus) herd. Ecol. Appl. 5:327-335.

Sellers, P.J. 1985. Canopy reflectance, photosynthesis and transpiration. Int. J. Remote Sensing 6, 1335-1372.

Teillet, P.M. and G. Fedosejevs. 1995. On the dark target approach to atmospheric correction of remotely sensed data. Can. J. Remote Sensing, Vol. 21, 374-387.

Thome, K., B. Markham, J. Barker, P. Slater, and S. Biggar. 1997. Radiometric calibration of Landsat. Photogrammetric Eng. and Remote Sensing, Vol. 63, 853-858.

Tucker, C.J. 1979. Red and photographic infrared linear combinations for monitoring vegetation. Remote Sens. Environ. 20, 127-150.
Vermote, E., D. Tanre, J. L. Deuze, M. Herman, and J.-J. Morcette. 1996. Second Simulation of the Satellite Signal in the Solar Spectrum (6S), IEEE Trans. Geosience and Remote Sensing, 35, 675-685.

Ward, D. and L. Olsvig-Whittaker. 1993. Plant species diversity at the junction of two desert biogeographic zones. Biodivers. Lett. 1: 172-185.

Ward, D., Olsvig-Whittaker, L. and Lawes, M. 1993. Vegetation-environment relationships in a Negev Desert erosion cirque. J. Veg. Sci. 4: 83-94.

Williamson, H.D. 1989. Reflectance from shrubs and under-shrub soil in a semi-arid environment. Remote Sens. Environ. 29, 263-271. 